J. Clin. Chem. Clin. Biochem.

Vol. 22, 1984, pp. 281-283

\title{
Abnormalities in Erythrocyte Membrane Protein in Pseudohypoparathyroidism Type $1^{1}$ )
}

\author{
By Akira Matsumoto and Takuo Fujita \\ The Third Department of Internal Medicine, Kobe University School of Medicine, Kobe, Japan
}

(Received August 2/October 17, 1983)

Summary: The erythrocyte membrane proteins of patients with pseudohypoparathyroidism type 1 and healthy volunteers were analysed by two-dimensional polyacrylamide gel electrophoresis in combination with a sensitive silver staining method. Electrophoretograms from patients were invariably different from control separations with respect to at least three protein spots. The possible relationship with the regulatory component of adenyl cyclase is discussed.

\section{Abweichungen im Proteinspektrum der Erythrocytenmembran bei Pseudohypoparathyreoidismus Typ 1}

Zusammenfassung: Die Proteine der Erythrocytenmembran wurden bei Patienten mit Pseudohypoparathyreoidismus Typ 1 und gesunden Probanden durch zweidimensionale Polyacrylamidgel-Elektrophorese in Verbindung mit einer empfindlichen Färbemethode mit Silber analysiert. Die Elektropherogramme von $\mathrm{Pa}-$ tienten unterschieden sich in jedem Falle in mindestens drei Proteinflecken von denen Gesunder. Die mögliche Beziehung zu der regulatorischen Untereinheit von Adenylatcyclase wird erörtert.

\section{Introduction}

Recently, the erythrocytes of patients with pseudohypoparathyroidism type 1 were shown to be deficient in adenyl cyclase regulatory component $(\mathrm{N}-$ protein), a membrane protein which couples hormonal stimuli to the enzymatic action of adenyl cyclase in the presence of GTP $(1,2)$. However, it is not known whether the N-protein is absent or functionally altered in these patients. In order to detect the biochemical difference of erythrocyte membrane proteins, if any, between patients with this genetic disorder and normal volunteers, two-dimensional gel electrophoresis in combination with a sensitive silver staining method was used.

\section{Materials and Methods}

General features of five patients and five healthy volunteers are summarized in table 1. All five patients, two of whom are brother

1) This work was supported in part by a Grant-in-Aid for Special Project Research, the Ministry of Education, Science and Culture of Japan. and sister, were diagnosed as typical and incomplicated pseudohypoparathyroidism type 1 on the basis of typical physical characteristics, hypocalcaemia, poor urinary excretion of phosphate as well as cyclic AMP in the Ellthworth-Howard test. None of these test subjects had taken drugs for two weeks preceding the sampling.

Blood samples $(4 \mathrm{ml})$ were drawn from the cubital vein into a heparinized syringe. After removing serum and buffy coat by centrifugation, erythrocytes were washed five times with $0.01 \mathrm{~mol} / \mathrm{l}$ phosphate buffered saline, $\mathrm{pH} 7.0$; ghosts were prepared according to Dodge et al. (3) with slight modifications: lysis buffer used was $0.01 \mathrm{~mol} / 1$ phosphate buffer $\mathrm{pH} 7.0$ with $2 \mathrm{mmol} / \mathrm{l}$ phenylmethylsulphonyl fluoride (Sigma, USA), a serine protease inhibitor.

Erythrocyte ghosts were thoroughly dialysed against water, lyophilized and dissolved in the lysis buffer as described by $O^{\prime}$ Farrell (4). Two-dimensional polyacrylamide gel electrophoresis was carried out according to the method of $O^{\prime}$ Farrell (4) with the following modifications: Concentrations of two Ampholines (LKB, Sweden) used in the first dimension disk gel and in the lysis buffer were $0.4 \%$ for Ampholine with pH range $5-7$ and $1.6 \%$ for that with $\mathrm{pH}$ range $3.5-10$. Those used in the sample overlay solution were $0.2 \%$ for Ampholine with pH range 5-7 and $0.8 \%$ for that with $\mathrm{pH}$ range 3.5-10. Polyacrylamide slab gels of $1 \mathrm{~mm}$ thickness and $10 \%$ concentration were used in the second dimension. Silver staining of slab gels was performed by the method of Merril et al. (5). Molecular weight markers used were; bovine serum albumin, 68000 , ovalbumin, 43000 and chymotrypsinogen b, 25700 . The $\mathrm{pH}$ gradient of the isoelectric focusing gel was determined by checking the $\mathrm{pH}$ of the water after incubating the $1 \mathrm{~cm}$ long disk gel slice with $500 \mu$ l of distilled water at $37^{\circ} \mathrm{C}$ for 1 hour. 


\section{Results}

Though some individual variations of spots were observed on two-dimensional gel electrophoretograms, several consistent differences were elucidated between five patients and five healthy yolunteers (fig. 1 and fig. 2). The 41 kilodalton protein spot with an isoelectric point of 4.3 was completely absent in the electrophoretograms of all five patients (solid arrows 1 in fig. 1 and 2). Also a constant subtotal deficiency of the 42 kilodalton protein spot with an isoelectric point of 4.4 was found in the electrophoretogram of all five patients (solid arrows 2 in fig. 1 and 2). Moreover, the 57 kilodalton protein spot with isoelectric point of 6.8 was completely absent in patients (dotted arrows in figs. 1 and 2). The results of individual cases are also summarized in table 1 .

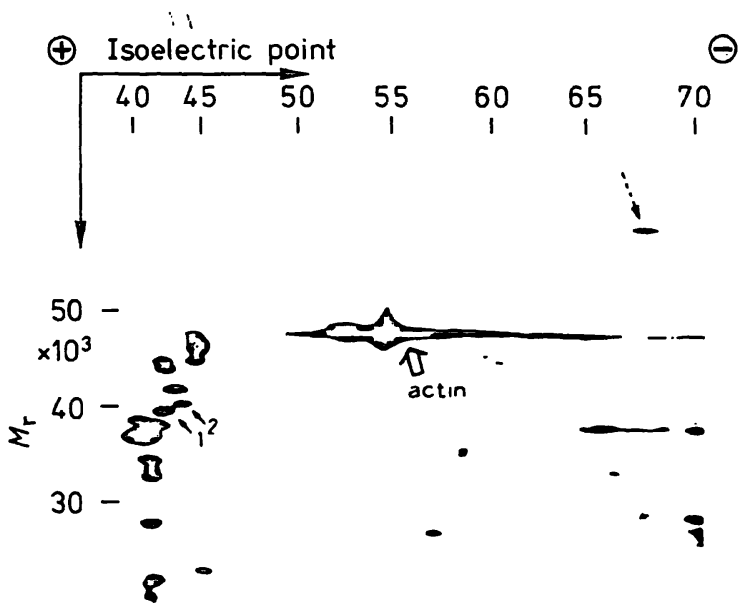

Fig. 1. Two-dimensional gel electrophoretogram of erythrocyte membrane proteins obtained from a healthy volunteer (case no. 6). The wide arrow indicates the position of actin.

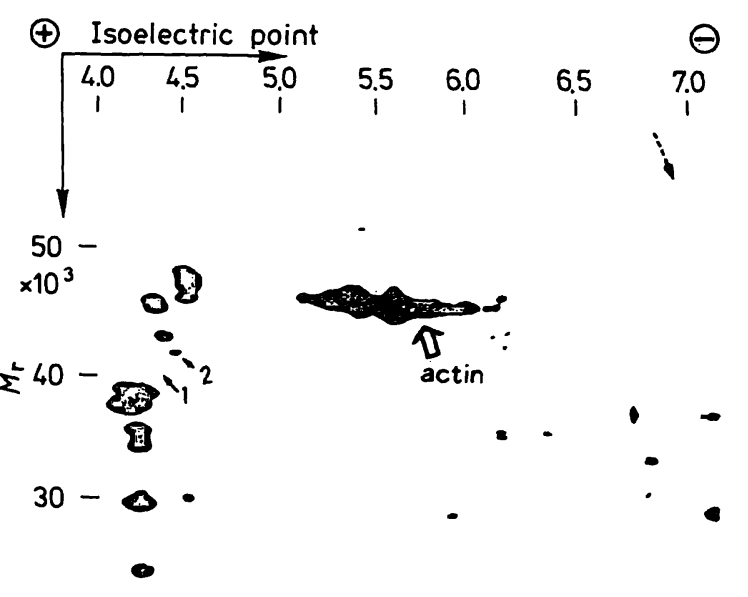

Fig. 2. Two-dimensional gel electrophoretogram of erythrocyte membrane proteins obtained from a patient with pseudo. hypoparathyroidism type 1 (case no. 1). The wide arrow indicates the position of actin.
Tab. 1. Summary of erythrocyte membrane proteins of interest from ten test subjects.

\begin{tabular}{llllll}
\hline $\begin{array}{l}\text { Case No. } \\
\text { (Name) }\end{array}$ & $\begin{array}{l}\text { Sex } \\
\text { Age }\end{array}$ & Diagnosis & $\begin{array}{l}\text { Abnormal protein } \\
\left(M_{\mathrm{r}} / \mathrm{pl}^{*}\right)\end{array}$ \\
& & & $41 \mathrm{~K} / 4.3$ & $42 \mathrm{~K} / 4.4$ & $57 \mathrm{~K} / 6.8$ \\
\hline & & & & \\
& & & & \\
$1(\mathrm{Kt})^{* *}$ & $\delta 25$ & PHP-1*** & $-* * * *$ & \pm & - \\
$2(\mathrm{Yt})^{* *}$ & $\$ 22$ & PHP-1 & - & - & - \\
$3(\mathrm{Ti})$ & $\delta 16$ & PHP-1 & - & - & \pm \\
$4(\mathrm{HW})$ & $\delta 15$ & PHP-1 & - & \pm & - \\
$5(\mathrm{Ski})$ & $\wp 62$ & PHP-1 & - & \pm & - \\
$6(\mathrm{Am})$ & $\delta 31$ & Normal & + & \pm & + \\
$7(\mathrm{Rm})$ & $\wp 29$ & Normal & + & + & + \\
$8(\mathrm{Ki})$ & $\delta 32$ & Normal & \pm & + & \pm \\
$9(\mathrm{Kn})$ & $\delta 18$ & Normal & + & $\neq$ & \pm \\
$10(\mathrm{Sku})$ & $\delta 63$ & Normal & \pm & \pm & + \\
\hline
\end{tabular}

* Isoelectric point.

** Case No. 1 and No. 2 are siblings.

*** Pseudohypoparathyroidism Type 1.

**** Relative intensity of protein spots are presented in symbols: ,,- \pm+ and $\neq$ represents absent, barely detectable, detectable and increased, respectively. The relative intensity of spots among each individual is determined by estimating the intensity in relation to the intensity of the actin zone on the same electrophoretogram.

\section{Discussion}

The $\mathrm{N}$-protein has recently been purified from rabbit liver plasma membranes $(6,7)$ as well as from turkey erythrocyte plasma membranes $(8,9)$. The protein complex isolated from rabbit liver plasma membranes consists of three subunits with molecular weights of approximately 52,45 and 35 kilodaltons. Turkey erythrocyte membranes have only two subunits with molecular weights of approximately 45 and 35 kilodaltons. The 45 kilodalton subunit has been proved to be a substrate for ADP-ribosylation in the presence of cholera toxin. In the case of human erythrocyte membrane, a 39 kilodalton protein was shown to be ADP-ribosylated in the presence of cholera toxin by Nielsen et al. (10). Kaslow et al. and Cooper et al. reported that a 42 kilodalton protein was ADP-ribosylated in the presence of cholera toxin (6) (11).

We report here a reduced concentration or absence of two proteins of this size (appr. 40 kilodaltons) in the erythrocytes of 5 patients with pseudohypoparathyroidism type 1 . This would explain the deficient $\mathrm{N}$-protein activity found in the majority of patients with this disease (1). Moreover, the result that more than one protein spot is decreased or absent may be related to the observed heterogeneity of this disorder $(10,12)$. When $\mathrm{N}$-protein prepared from a murine lymphoma cell line is separated by two-di- 
mensional gel electrophoresis, both 45 and 55 kilodalton proteins are shown to be composed of several spots with approximate isoelectric points of 5.6 and 5.8 , respectively (13). The reason for the difference of isoelectric point between the human erythrocyte and murine lymphoma cell proteins is not known, but it may be due to species and/or organ difference.

Two-dimensional polyacrylamide gel electrophoresis in combination with silver staining method accomp- lished the highest resolution thus far obtained in erythrocyte membrane protein analysis. Metabolic labeling of erythrocyte membrane protein using radioactive amino acids is not advisable due to the poor metabolic activity of erythrocytes. The electrophoretic method described here, however, provides an effective strategy for research into any genetic disease abnormality which is expressed in erythrocyte membrane protein, e.g. myotonic dystrophy and Duchenne-type muscular dystrophy (14).

\section{References}

1. Levine, M. A., Downs, R. W. Jr., Singer, M., Marx, S. J., Aurbach, G. D. \& Spiegel, A. M. (1980) Biochem. Biophys. Res. Commun. 94, 1319-1324.

2. Farfel, Z., Brickman, A. S., Kaslow, H. R., Brothers, V. M. \& Bourne, H. R. (1980) New Engl. J. Med. 303, 237-242.

3. Dodge, J. T., Mitchell, C. \& Hanahan, D. J. (1963) Arch. Biochem. Biophys. 100, 119-130.

4. O'Farrell, P. H. (1975) J. Biol. Chem. 250, 4007-4021.

5. Merril, C. R., Goldman, D., Sedman, S. A., Ebert, M. H. (1981) Science 211, 1437-1438.

6. Kaslow, H. R., Johnson, G. L., Brothers, V., Bourne, H. R. (1978) Mol. Pharmacol. 15, 472-483.

7. Sternweis, P. C., Northup, J. K., Smigel, M. D., Schleifer, L. S., Gilman, A. G. (1981) J. Biol. Chem. 256, 11517-11526.

8. Northup, J. K., Sternweis, P. C., Smigel, M. D., Schleifer, L. S., Ross, E. M., Gilman, A. G. (1980) Proc. Natl. Acad. Sci. U.S.A 77, 6516-6520.

9. Sternweis, P. C., Northup, J. K., Hanski, E., Schleifer, L. S., Smigel, M. D., Gilman, A. G. (1981) Adv. Cyclic Nucleotide Res. 14, 23-36.

10. Nielsen, T. B, Lad, P. M., Rreston, M. S., Rodbell, M. (1980) Biochim. Biophys. Acta 629, 143-155.

11. Cooper, D. M. F., Jagus, R., Somers, R. L., Rodbell, M. (1981) Biochem. Biophys. Res. Commun. 101, 1179-1185.

12. Rodbell, M. (1980) Nature 284, 17-22.

13. Schleifer, L. S., Garrison, J. C., Sternweis, P. C., Northup, J. K., Gilman, A. G. (1980) J. Biol. Chem. 255, 2641-2644.

14. Brown, H. D., Chattopadhyay, S. K., Patel, A. B. (1967) Science 157, 1577-1578.

Dr. Akira Matsumoto

Dept. of Pathology

Kyoto University

Faculty of Medicine

Joshida-Konoe

Sakyo-ku

Kyoto, Japan, 606 
